ELORE (ISSN 1456-3010), vol. 20 - 2/2013.

Julkaisija: Suomen Kansantietouden Tutkijain Seura ry.

[http://www.elore.fi/arkisto/2_13/miettinen.pdf]

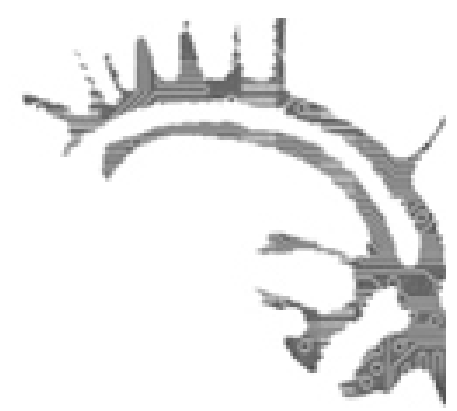

SEMINAARIRAPORTTI

\title{
NOITUUTTA, TAIKUUTTA JA KANSANUSKOA ENNEN JA NYT
}

\author{
$\underline{\text { Riikka Miettinen }}$
}

Witchcraft, Magic and Popular Religion - XI Gustav Vasa Seminar 11.-12.6.2013 Jyväskylän yliopistossa

Jyväskylän yliopiston historian ja etnologian laitoksen vuosittain järjestämä Kustaa Vaasa -seminaari kokosi kesäiseen Keski-Suomeen erityisesti historian, etnologian ja uskontotieteen tutkijoita niin kotimaasta kuin kauempaakin. Tämänvuotisen, järjestyksessään 11. seminaarin teemoina olivat noituus, taikuus ja kansanusko, joita käsiteltiin menneissä ja nykyisissä kulttuureissa, aina varhaiskeskiajan Irlannista postmoderniin virtuaalimaailmaan. Aihepiiri sopi loistavasti Jyväskylässä järjestettävään seminaariin, sillä yliopiston historian ja etnologian laitoksella työskentelee lukuisia tematiikkaan erikoistuneita tutkijoita. Kansainvälinen seminaari tarjosi monipuolisen kattauksen erilaisista uskomuksiin ja rituaaleihin liittyvistä tutkimuskohteista sekä niihin liittyvästä ajankohtaisesta keskustelusta, jota käytiin vilkkaana myös työryhmissä ja esitelmien jälkeen. Osallistujia saapui perinteiseen tapaan erityisesti Suomen yliopistoista, mutta myös muualta Euroopasta ja Australiasta asti. Etnologian, uskontotieteen, arkeologian ja sosiologian tieteenalojen edustajat toivat seminaariin toivottua monitieteisyyttä, vaikkakin historiantutkijat muodostivat osallistujista selkeän enemmistön. Seminaarin poikkitieteellisyys ilmeni myös lukuisissa esitelmissä, joissa yhdisteltiin eri tieteenalojen 
Riikka Miettinen: Noituutta, taikuutta ja kansanuskoa ennen ja nyt

teorioita, näkökulmia ja metodologiaa sekä erityyppisiä aineistoja. Käsittelen seminaarissa esille nousseita keskeisimpiä kysymyksiä ja keskusteluita sekä varsinaisia esitelmiä enimmäkseen teemoittain, sillä vaikka esitelmien jaottelua oli tehty jonkin verran käsiteltävän aikakauden mukaisesti, sessiot eivät muodostaneet selkeitä kokonaisuuksia.

\section{YLILUONNOLLISEN LÄSNÄOLO JA KOKEMUS MENNEESSÄ MAAILMASSA}

Tapahtuman avasi historiantutkija Jari Eilolan (Jyväskylän yliopisto) katsaus seminaarin teemoihin ja erityisesti eri tieteenalojen tuomien uusien näkökulmien hyödyllisyydestä noituuden, taikuuden ja kansanuskon tutkimukselle. Tuoreet tutkimuskohteet sekä toisaalta erilaiset näkökulmat klassikoiksi muodostuneisiin aiheisiin ovat monipuolistaneet käsityksiämme niin esimodernin kuin uudempien aikojenkin uskonnonharjoituksesta ja maailmankuvasta. Osuvana esimerkkinä Eilola piti kuvaa noituuden ja taikuuden harjoittamisesta ja merkityksestä; sen sijaan, että niitä pidettäisiin marginaalisina, salaisten kulttien rituaaleina, tutkimus on osoittanut, kuinka yliluonnollisilla voimilla ja niiden hyödyntämisellä oli keskeinen osansa ja funktionsa entisajan ihmisten kokemusmaailmassa.

Etnologian professori Laura Stark (Jyväskylän yliopisto) käsitteli keynote-esitelmässään laajan suomalaisen kansanperinneaineiston pohjalta vanhojen maatalousyhteisöjen taikauskoa, käsityksiä yliluonnollisista voimista ja eritoten niiden merkitystä toimijuuden ja ruumiskäsitysten kannalta. Myös historian professori Jacqueline Van Gent (University of Western Australia) pureutui keynote-esitelmässään ruumiskäsitysten, tunteiden ja yliluonnollisten voimien suhteisiin. Uuden ajan alun sukupuoli- ja uskontohistoriaan erikoistunut Van Gent on mukana Australiassa toimivassa tutkimuskeskuksessa (ARC Centre of Excellence for the History of Emotions), jossa tehdään uraauurtavaa tutkimusta tunteiden historiasta. Keynote-puhujat toivat esiin, kuinka taikuuden harjoittaminen oli ihmisille ennen kaikkea keino hallita varsin turvatonta, luonnonvoimien varaan rakennettua elämäänsä. Koska usko yliluonnolliseen maailmaan ja sen mahtiin oli vahvasti jaettu ja sisäistetty, taikuus ja noituus olivat todellisia ajan ihmisille, ja siten niillä saattoi olla todellisia vaikutuksia - ihmiset esimerkiksi sairastuivat tai parantuivat noitien ja tietäjien toimista.

Mennyttä ihmistä on pohjimmiltaan mahdotonta ymmärtää ilman käsitystä yliluonnollisen sisältävästä maailmankuvasta ja erilaisesta ihmiskuvasta, jonka oleellinen osa oli näkemys ihmisvartalosta ulkoisille voimille alttiina tilana. "Itseys" ja keho sekä niiden rajat koettiin läpäisevämpinä ja alttiimpina niin tunteiden kuin ulkopuolisten voimien ja sosiaalisten suhteiden vaikutuksille. Sosiaalinen ja yliluonnollinen koettiin somaattisesti, jolloin esimerkiksi vihan, riitojen ja noituuden tulkittiin voivan aiheuttaa sairauksia ja muita ruumiillisia oireita. Ruumiinaukot ja vahvat tunnepurkaukset altistivat ihmisen yliluonnollisten voimien hyökkäyksille. Niinpä rajojen vartiointi taikojen ja erilaisten rituaalien avulla oli entisajan ihmisille keskeistä. Van Gent tähdensi myös tunteiden sisällön, ilmaisemisen, funktioiden ja säätelyn tutkimuksen tärkeyttä taikuutta, noituutta 
Riikka Miettinen: Noituutta, taikuutta ja kansanuskoa ennen ja nyt

ja kansanuskoa tarkasteltaessa; tunnetilojen sosiaalista voimaa tai käsitystä tunteiden materialisoitumisesta ja vaarallisuudesta ei voida ohittaa selitettäessä ihmisten käyttäytymistä. Keskusteluissa korostettiin historiantutkimuksen ja etnologian tulosten ja aineistojen yhdistämisen hyödyllisyyttä sekä punnittiin vanhemman ihmis- ja ruumiinkuvan mekanismeja ja sosiaalisia merkityksiä. Sekä Stark että Van Gent peräänkuuluttivat lisää tutkimusta ja monipuolisten aineistojen sekoittamista, sillä menneiden kulttuurien uskonelämässä, taikauskossa ja niiden ilmenemismuodoissa on vielä paljon selvitettävää.

\section{Hairahtuneet, PAHOLAisen KiUSAamat JA NOIDAT - VÄRIKÄSTÄ KANSANUSKOA KESKIAJALLA JA UUDEN AJAN ALUSSA}

Useissa esitelmissä käsiteltiin noituutta, taikuutta sekä uskoon ja yliluonnolliseen liittyviä käsityksiä keskiajan ja uuden ajan alun Euroopassa. Kolmas keynote-puhuja, historiantutkija Caterina Bruschi (University of Birmingham) tarkasteli keskiajan kerettiläisyysoikeudenkäyntien kautta harhaoppisina pidettyjen synkretististen kansanuskon muotojen tukahduttamista ja erityisesti tutkinnan kulkua ja toimijoiden rooleja. Toisin kuin yleensä oletetaan, tutkinnoissa ei tavallisesti käytetty kidutusta; inkvisiittorien päätavoitteena oli pelastaa väärinajattelevan sielu ja saada hänet katumaan sekä hyväksymään katolisen kirkon dogmit. Epäiltyjen kuulustelu oli Bruschin mukaan eräänlaista psykologista peliä, jossa niin ammattimaiset inkvisiittorit apureineen kuin syytetytkin käyttivät erilaisia strategioita onnistuakseen tavoitteissaan. Tunnetusti keskiajan ja uuden ajan alun noituutta, taikuutta ja kansanuskon muotoja tutkittaessa joudutaan tukeutumaan etupäässä oikeudellisiin lähteisiin; Bruschin esitelmä tarjosikin ennen kaikkea hyödyllisiä lähdekriittisiä näkökulmia erilaisten oikeudellisten aineistojen käyttöön sekä työkaluja niiden muodon ja osallistujien toiminnan ymmärtämiseen.

Kirkon dogmeja ja opetusta ei luonnollisesti täysin seurattu tai noudatettu myöskään uuden ajan alun Ruotsissa ja Suomessa. 1600- ja 1700-lukujen suomalaiseen ja ruotsalaiseen uskonnonharjoitukseen keskittyvässä sessiossa pitämäni esitelmä käsitteli itsensä surmanneiden ruotsalaisten ja suomalaisten uskonkriisejä ja puhdasoppisen kirkon linjasta poikkeavia tulkintoja pelastuksestaan. Monet eivät suinkaan hyväksyneet vuosisataista näkemystä itsemurhaajan päätymisestä helvettiin. Toisaalta itsemurhaan liittyvät uskomukset ja huoli sielun kohtalosta ajoivat elämänsä päättämisestä haaveilleita ihmisiä tekemään erilaisia rikoksia kuolemantuomion toivossa. Samassa yhteydessä myös historiantutkijat Miia Kuha ja Emmi Lahti (Jyväskylän yliopisto) esittelivät omien tutkimusaiheidensa kautta kansan epäsovinnaisia uskonnon harjoittamisen tapoja. Savolaisten pyhäpäivien vietto ja uskonnonharjoitus ei noudattanut puhdasoppisen kirkon ideaaleja, vaan kansa jatkoi perinteisiä tapojaan, joissa sekoittuivat niin muinaisuskon rituaalit kuin katoliset tavat. Lahden tarkastelema hautausmaataikuus ja ruumiinosien käyttö taikuudessa ilmentää, kuinka kansanuskon keskeisimmät elementit, käsitys ominaisuuksien ja voimien tartunnasta sekä pars pro toto-periaate yhdistettiin kristillisiin käsityksiin ja kirkon näkemyksiin pyhästä. Pyhinä pidetyt ajat ja paikat ja niihin liittyvät rituaalit rakentuivat kristinuskon ja kansanuskon risteyksessä. Keskusteluissa pohdittiin- 
kin, onko edes mahdollista tai oleellista erottaa uskoja, tai ns. eliitin ja kansan kulttuureja ja niiden ominaisuuksia toisistaan. Myös myöhemmin vanhempien aikojen noituuteen ja taikuuteen liittyvässä sessiossa puhuneen uskontotieteilijä Ilona Tuomen (University College Cork) esitys liittyi samaan tematiikkaan; Tuomen esittelemät varhaiskeskiaikaiset irlantilaiset loitsut ja niiden kelttiläiset ja kristilliset ainekset ilmensivät, kuinka erilaiset uskonjärjestelmät ovat aina ja väistämättä yhteensulautuneet ja muovanneet uskontoja ja uskonnonharjoitusta.

Lisää vanhempien aikojen uskonelämää valotti historiantutkija Sari Katajala-Peltomaan (Tampereen yliopisto), Meri Heinosen (Turun yliopisto) ja Raisa Maria Toivon (Tampereen yliopisto) paholaisaiheinen sessio esityksineen. Paholainen saattoi riivata keskiajalla niin naisia kuin miehiäkin, joiden oireet muistuttivat raivotaudiksikin kutsutun mielisairauden ilmentymiä; tiloja tunnistaneisiin ja luokitelleisiin pappeihin vaikuttivat kärsivän sosiaalinen asema, sääty ja maine. Demonit kiusasivat myös saksalaisia nunnia, joiden kuvattiin kohtaavan pahojen voimia erityisesti luostarielämänsä siirtymäja liminaalivaiheissa. Koettelemusten kirjaamisella tulevien nunnien luettaviksi pyrittiin lujittamaan sisarten yhteisöllisyyttä ja valmistelemaan nuorempia luostarielämään ja sen haasteisiin. Sen sijaan paholaisella ei ollut suurta roolia 1600-luvun Suomen noituus- ja taikuusoikeudenkäynneissä. Vaikka oikeutta käytiin näissä asioissa ennätyksellisen paljon suhteessa väkilukuun, muualla Euroopassa ja Pohjolassakin vahvistunut diabolismi ei juurtunut Suomeen - noituus ja taikuus liittyivät arkisiin asioihin ja elinkeinoihin, eikä liitoista tai suhteista paholaisen kanssa juurikaan puhuttu.

Aihetta täydensivät sopivasti myöhemmät esimodernin ajan noituuteen ja taikuuteen liittyvät esitelmät. Professori Liv Helene Willumsenin (Tromssan yliopisto) esittelemissä Pohjois-Norjan massiivisissa noitavainoissa diabolismi ja paholaisliitot olivat pääosassa. Willumsen korosti noitapaniikkien kontekstoinnin tärkeyttä. Esimerkiksi Norjassa oppineet ja valtaapitävät tanskalaiset toivat mukanaan demonologiset ideat, ja vainot liittyivät läheisesti valtapoliittisiin murrosvaiheisiin ja vallanvaihdoksiin. Paholaissuhteet kukoistivat myös saman ajan Englannissa ainakin noitia kuvanneissa pamfleteissa, joissa erityisesti tunteellisesti epätasapainoiset ja heikot naiset olivat alttiita paholaisen manipuloinnille, kuten historiantutkija Charlotte-Rose Millar (University of Melbourne) toi esitelmässään esiin. Toisin kuin Suomessa, Pohjois-Norjassa ja Englannissa noituudesta syytetyistä valtaosa oli naisia, mikä osaltaan liittyi oppineiden demonologisiin visioihin. Pitkään käyty keskustelu diabolismin alueellisen levinneisyyden eroista ja niiden syistä virisi myös seminaarissa; tietyillä alueilla oppi selvästi sopi paremmin vallitsevaan kulttuuriin ja valtaapitävien tarpeisiin.

Seminaarin esitelmissä ja keskusteluissa toistuvana aiheena oli myös uskonharjoittamisen ja erilaisten rituaalien sukupuolittuneisuus. Niin keskiajan kuin uuden ajan alunkin Euroopassa ja Pohjolassa joitakin poikkeuksia lukuun ottamatta naisten uskottiin joutuvan demonien riivaamiksi, manipuloimiksi ja uhreiksi ja harjoittavan enemmän noituutta ja taikuutta kuin miesten. Naisten yliedustus noituuden ja taikuuden harjoittajina liittynee monin paikoin sukupuolittuneeseen työnjakoon, mikä luontaisesti vaikutti myös eroihin uskonnonharjoittamisessa ylipäätään. Esimerkiksi uskontotieteilijä ja kirkkohistorioitsija Teuvo Laitilan (Itä-Suomen yliopisto) esitelmässään käsittelemä ortodoksisen kirkon naispyhä Paraskeva vetosi erityisesti naisiin; pellavankudontaan 
Riikka Miettinen: Noituutta, taikuutta ja kansanuskoa ennen ja nyt

liittyvä hahmo oli luontaisesti tärkeä kodin piirissä toteutetun elinkeinon harjoittajille itäisissä yhteisöissä.

\section{TAIKAUSKON JA RITUAALIEN JATKUMOT}

Kansanomaisten rituaalien jatkuvuudet ja uskonnollisten tapojen muutosten hitaus tulivat esiin lukuisissa esitelmissä. Esimerkiksi Miia Kuhan sekä Emmi Lahden pyhiin aikoihin ja paikkoihin liittyvät tutkimuskohteet ja esitelmät kuvastivat osuvasti uuden ajan alun Suomen uskontokulttuurin ja eletyn uskonnon synkretistisyyttä; kansanusko, taikausko ja kristinusko sekoittuivat, ja vanhoja perinteitä jatkettiin pitkään. Myös historiantutkija Sofia Kotilaisen (Jyväskylän yliopisto) esitys nimenantoon liittyvistä rituaaleista ja uskomuksista 1800-luvun ja 1900-luvun alun Suomessa liittyi tapojen pitkäkestoisuuteen ja sitkeyteen. Lisääntyvä ja leviävä lukutaito ei katkaissut maaseudun vahvoja nimenantoperinteitä. Arkeologi Sonja Hukantaival (Turun yliopisto) toi näkökulmaa kotipiiriin liittyvän taikuuden harjoittamisesta Suomessa yhdistäen arkeologian ja kansanperinteen tietoa. Arkeologiset löydöt osoittavat, kuinka taikausko jätti fyysisiä jälkiä maailmaan. Erilaisten taikaesineiden, erityisesti tiettyjen eläinten luiden ja osien, piilottamisella koti- tai pihapiiriin pyrittiin vuosisatojen ajan vaikuttamaan onneen ja turvaan. Kotilaisen ja Hukantaipaleen esitelmät toivat hyvin esiin myös erilaisten lähdeaineistojen yhdistelemisen edut. Menneisyyden asiakirjat, monipuolinen kansanperinteemme ja arkeologiset löydökset rikastuttavat kuvaamme menneistä tavoista ja yhdistettynä paljastavat yllättävääkin tietoa. Yksi suosituista esitelmissä ja muissakin keskusteluissa käsitellyistä kysymyksistä liittyi perinteisesti folkloreaineistojen edustavuuteen ja käytettävyyteen; selvää on, että niiden perusteellinen kontekstointi on oleellista ja että niissä esiintyvien uskomusten jatkuvuutta, muuttumattomuutta ja yleistettävyyttä tulee välttämättä tarkastella kriittisesti.

Noituuden, taikuuden ja kansanuskon historiaan liittyvien aiheiden lisäksi seminaarissa kuultiin mielenkiintoisia esitelmiä tuoreemmista uskonmuodoista ja erilaisten rituaalien ja taikauskon jatkumoista ja säilyvyydestä nykyisissä länsimaissa. Uudempiin aikoihin liittyvät esitykset käsiteltiin omissa sessioissaan tiistaina ja keskiviikkona. Folkloristi Reet Hiiemäen (Tarton yliopisto) esitelmä käsitteli ruokiin liittyvien uskomuksien pitkän keston jatkuvuuksia. Uskontotieteilijä Outi Pohjanheimo (Helsingin yliopisto) tarkasteli vaihtoehtohoitojen ja erityisesti reikihoidon harjoittajien taikauskoon perustuvaa intuitiivista ajattelua ja sen sisäistämistä. Myös uskontotieteilijä Matouš Vencálekin (Masaryk University) ja uskontotieteilijä Essi Mäkelän (Helsingin yliopisto) esitykset liittyivät moderniin vaihtoehto- ja uususkonnollisuuteen. Vencálek tarkasteli uuspakanallisista liikkeistä druidismia, ja sitä, kuinka kelttiläisestä perinteestä haetuille rituaaleille on annettu liikkeessä uusia, ekologisia ja sukupuolten tasa-arvoon liittyviä sisältöjä ja merkityksiä. Mäkelä esitteli 1950-luvulla syntynyttä diskordianismia, joka parodiauskonnon luonteestaan huolimatta merkitsee harjoittajilleen paitsi elämäntapaa myös humoristista keinoa selviytyä nykymaailman haasteista. Sosiologi Francesco Pirainon (Istituto italiano di Scienze Umane) ja Laura Zambellin (Milano Bicocca University) 
Riikka Miettinen: Noituutta, taikuutta ja kansanuskoa ennen ja nyt

esitelmä liittyi niin ikään elettyyn uskontoon länsimaissa. Etelä-Italiassa toimivat Pyhän Rosalian ja Mamma Schiavonan kultit ovat tiettyjen vähemmistöryhmien suosiossa; tamilit ja romanit rakentavat uusitalialaista identiteettiään sulauttaen perinteitään Pyhän Rosalian palvontaan, ja homo- ja transseksuaalit löytävät itselleen tilaa katoliselta kentältä Mamma Schiavonan kautta.

Esitelmiltään kirjava seminaari osoitti, että vaikka osa menneen maailman taioista, rituaaleista ja uskomuksista katosi, tietyt perinteet ja käsitykset säilyivät pitkään. Nykyinen uskonnollisten liikkeiden kirjokin ilmentää hyvin sitä, että taipumus uskoa yliluonnollisiin ilmiöihin on pinttynyt syvälle ihmisten aivoihin ja elää edelleen sitkeästi. On selvää, että niin menneiden aikojen kuin nykyajankin monivivahteisen uskomusmaailman kentillä riittää paljon tutkittavaa. Useimmat seminaarin esitelmistä näyttivät, että keskusteluissakin peräänkuulutettuun tarpeeseen ja kysyntään monitieteellisestä, erityyppisiä metodeja ja aineistoja hyödyntävästä ja ilmiöiden pitkän keston muutoksia ja jatkuvuuksia tarkastelevasta tutkimuksesta ollaan vastaamassa. Järjestelyiltään seminaari oli tuttuun tapaan erinomainen, ja se tarjosi mahdollisuuden paitsi uusien kontaktien luomiselle myös tuoreisiin aiheisiin ja tutkimustapoihin tutustumiselle. Aiheiden moninaisuus ja mahdollisuudet, tutkimukselliset ja aineistoihin liittyvät haasteet sekä keskustelujen vilkkaus osoitti, että noituuden, taikuuden ja kansanuskon tutkimuskentällä riittää varmasti kuhinaa.

Filosofian lisensiaatti Riikka Miettinen on tohtorikoulutettava Tampereen yliopistossa. 